\title{
DIFFERENCES IN THE CELL WALL ARCHITECTURE OF MELANIN LACKING AND MELANIN PRODUCING CRYPTOCOCCUS NEOFORMANS CLINICAL ISOLATES FROM INDIA: AN ELECTRON MICROSCOPIC STUDY
}

\author{
Piyali Mandal'; Tara S. Roy ${ }^{2}$; Taposh K. Das²; Uma Banerjee ${ }^{1}$; Immaculata Xess ${ }^{1}$; Joshua D. Nosanchuk ${ }^{3 *}$ \\ ${ }^{1}$ Departments of Microbiology and ${ }^{2}$ Anatomy, All India Institute of Medical Sciences, New Delhi, India; ${ }^{3}$ Department Medicine, \\ Albert Einstein College of Medicine, Bronx, New York, USA.
}

Submitted: June 08, 2007; Returned to authors for corrections: July 30, 2007; Approved: September 20, 2007.

\begin{abstract}
Cryptococcus neoformans is an important opportunistic fungal pathogen that causes life-threatening infection of the central nervous system. A major virulence factor for $C$. neoformans is the production of melanin in the cell wall. Using transmission electron microscopy, we studied the cell walls of three pairs of isolates obtained from patients with dual cryptococcal infections, where a melanotic and an albino strain were isolated from the CSF of each patient. Transmission Electron Microscopy revealed that the albino strains lacked a melanin layer whereas a melanin layer was associated with the cell wall of the melanotic strains, comprising approximately $75 \%$ of the cell wall area. The cell wall size of the melanin producing cells was approximately double the size the albino isolates' cell walls ( $p$ value $\leq 0.003$ ). In this study TEM revealed that the differences in the ultrastructure of the melanin lacking and melanin producing isolates were associated to the cell wall and the melanin layer.
\end{abstract}

Key words: Cryptococcus neoformans, Melanin, TEM, Cell wall

\section{INTRODUCTION}

C. neoformans is a capsulated environmental fungus belonging to the basidiomycetes family that causes lifethreatening infections in immunocompromised and immunocompetent hosts $(2,4)$. In addition to the production of a polysaccharide capsule, the production of melanin in the fungal cell wall is essential for virulence (15). Melanization of $C$. neoformans protects the organism from various environmental conditions, such as the presence of toxins, extreme temperatures, ultraviolet radiation and heavy metals $(9,22,28,29)$. Melanin also shields the fungus from environmental predation by microorganisms such as Acanthamoeba castellani and Caenorhabditis elegans $(19,24)$. During infection, melanin interferes with the development of effective cell mediated responses $(10,18)$. Furthermore, melanized cells are more resistant to the effects of certain antifungals, such as amphotericin $\mathrm{B}$ and caspofungin $(11,26,28)$, and are less sensitive to microbicidal oxidants (29). Hence, melanization has clinical implications for cryptococcosis since the pigment reduces the host response and the potency of antimicrobial therapy.

Melanin-like compounds are present in the cell wall $(8,20,21,30)$. Scanning Electron Microscopy (SEM), Atomic Force Microscopy (AFM), and Transmission Electron Microscopy (TEM) have revealed that cell wall melanin is composed of granules with roughly uniform dimensions (8). These studies have also shown that the melanin is degraded or remolded during budding of $C$. neoformans (8). However, the techniques have not been utilized to study the cell wall of melanin-lacking primary $C$. neoformans clinical isolates. We previously described three patients from each of whom distinct albino and melanotic isolates were identified in primary cultures of their CSF (16). The purpose of this study is to determine

*Corresponding Author. Mailing address: Abert Einstein College of Medicine, Jack and Pearl Resnick Campus, 1300 Morris Park Avenue, Ullman Building, Room 107, Bronx, NY 10461. E-mail: nosanchu@aecom.yu.edu 
differences in the cell walls of these albino and pigmented $C$. neoformans isolates based on TEM analysis.

The data in this paper are from a thesis submitted by Piyali Mandal in partial fulfillment of the requirements for the degree of doctor of philosophy in the Department of Microbiology, AIIMS, New Delhi, India.

\section{METHODS}

\section{Cultures}

Colonies from primary isolates from 43 patients with cryptococcal meningitis were screened for melanin production on Caffeic acid ferric citrate agar medium (Himedia, India) at All India Institute of Medical Sciences (AIIMS) (16). In three patients melanized and white colonies were isolated. For the present work, the three pairs of isolates were studied $(500 \mathrm{w}, 500 \mathrm{~b}$; $716 \mathrm{w}$, $716 \mathrm{~b}$ and $764 \mathrm{w}, 764 \mathrm{~b}$ ), where ' $w$ ' and 'b' represent white and black, respectively. The ' $w$ ' strains were albino when grown with phenolic substrates whereas the ' $b$ ' strains were pigmented and melanin particles could only be isolated from the 'b' strains. The strains were maintained on Sabouraud's dextrose agar.

\section{TEM}

Single colonies were grown in Sabouraud's dextrose broth with $1 \mathrm{mM}$ L-DOPA for 7 days at $30^{\circ} \mathrm{C}$ at $150 \mathrm{rpm}$. The cells were collected by centrifugation at $2000 \mathrm{rpm}$ for 10 minutes and washed twice with PBS. The cells were suspended in Cadillac fixative (2.5\% gluteraldehyde, $1.2 \%$ acrolein in symcollidine) at room temperature followed by washing with 0.1 $\mathrm{M}$ cacodylate buffer twice for 5 minutes each. The cells were subjected to postfixation in $1 \%$ Osmium tetroxide for $90 \mathrm{~min}$ at room temperature followed by resuspending the pellet once in $0.1 \mathrm{M}$ cacodylate buffer for $10 \mathrm{~min}$, washed with distilled water for $10 \mathrm{~min}$ and dehydrated with ascending grades $(30 \%$, $50 \%, 70 \%, 95 \%, 100 \%$ and $100 \%$ again) of ethanol. The pellet was then washed with a solution of ethanol and propylene oxide at $1: 1$ ratio for 10 minutes followed by propylene oxide for 10 minutes twice. Infiltration was done in Spurrs resin containing propylene oxide at 1:1 ratio for $5 \mathrm{hrs}$ under vaccum and at 3:1 ratio for 10 minutes twice under vacuum. Embedding was done in spurrs resin under vaccum at $60^{\circ} \mathrm{C}$ for $48 \mathrm{hrs}$. Blocks of 70 - $80 \mathrm{~nm}$ thickness were cut on a Reichart Ultracut UCT and sections were placed on copper grids and stained with $2 \%$ uranyl acetate and $0.5 \%$ lead citrate for $90 \mathrm{~min}$. The samples were viewed and analyzed with a JEOL (Peabody, MA, USA) 1200EX transmission Electron Microscope at 80 $\mathrm{kV}$. The figures obtained by electron microscopy were used to determine the differences between the cell wall ultrastructure of the melanotic and albino strains. Twenty cells for each strain were measured using adobe photoshop 7.0.1. The diameter of the cell and the thickness of the cell wall were determined and the mean and standard deviation were calculated using
Microsoft excel. The ratio of cell size (without cell wall size) to cell wall size were determined.

\section{RESULTS}

TEM revealed the presence of melanin as an electron dense layer in the cell wall of the melanin-producing isolates (Fig. 1b). The melanin layer was distributed throughout the cell wall in the form of concentric rings (Fig. 2). In the majority of cells the melanin layer was spread through approximately $75 \%$ of the cell wall area. The melanin layer was disrupted at the budding sites in the mother cells and the separated daughter cells had complete, melanized cell walls, albeit significantly thinner melanin layers (Fig. 3). In fact, analysis of 10 mother-daughter cells with nearly complete budding revealed that the melanin layers of the mother cells ranged from $0.125-0.443 \mu \mathrm{m}$ (mean $0.281 \mu \mathrm{m}$ ) whereas the layers of daughter cells were $0.043-$ $0.077 \mu \mathrm{m}$ (mean $0.068 \mu \mathrm{m}, \mathrm{p}=0.003$ ). In contrast, mother and

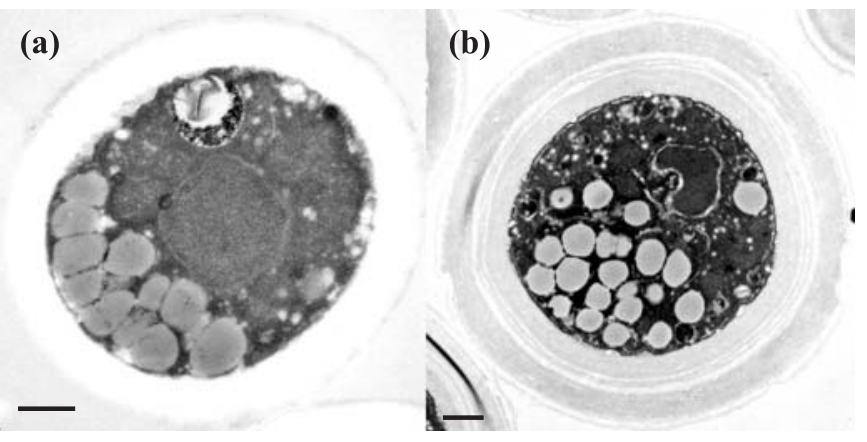

Figure 1. TEM of (a) melanin-lacking (500w) and (b) melaninproducing (500b) C. neofomans cells grown in L-DOPA medium for 7 days. Similar results were obtained with the other two pars of isolates. Scale bar, 500nm, (Magnification X 15000).
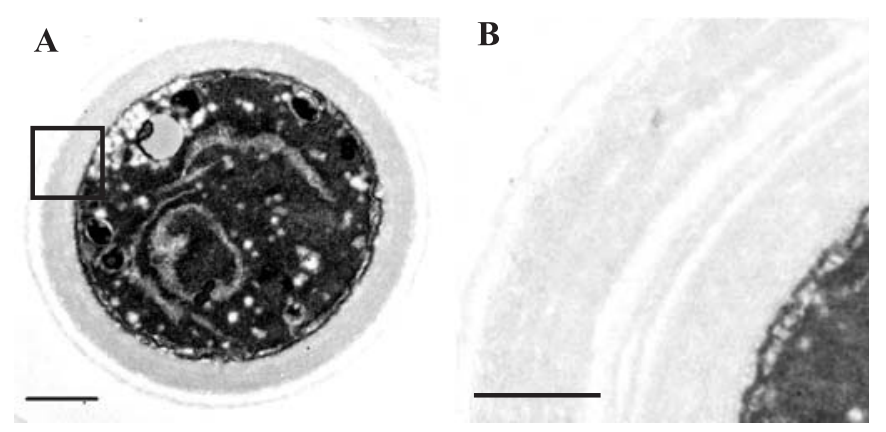

Figure 2. TEM of a melanotic C. neoformans cell (A) showing the concentric ring structure (B) of the melanin layer. Scale bar, 500nm, (Magnification X 10000). 


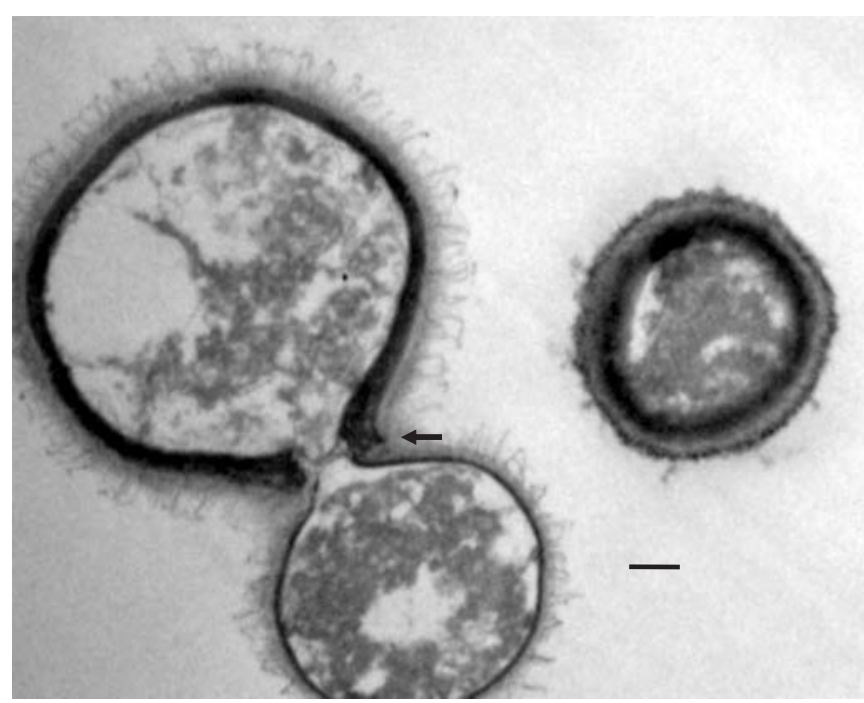

Figure 3. TEM of melanotic C. neoformans cells showing the disrupted edges of the mother cell while budding and the formation of complete melanin layers in recently budded cells. The fibrilar structures visualized on the cell surface are polysaccharide components of the fungal capsule. Scale bar, $500 \mathrm{~nm}$, (Magnification X 1400).

daughter albino-type cells grown with L- DOPA medium lacked an electron dense layer in their cell walls (Fig. 1-a and 4-b). As represented in Figure 4, the cell wall size of the melanin producing cells was approximately double the size the albino isolates' cell walls (Table 1). Twenty cells from each sample were analyzed and the difference was significant with the $p$ value $\leq 0.003$ by Student's $t$ test for all the three pairs of isolates. The cell wall sizes of other melanotic isolates were also studied by TEM and (a)

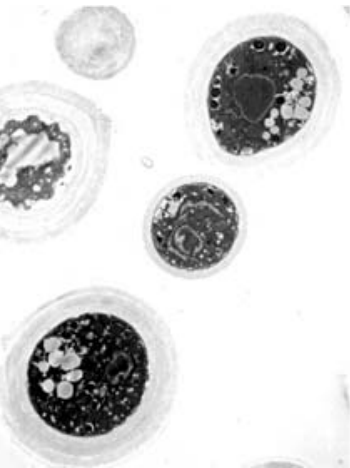

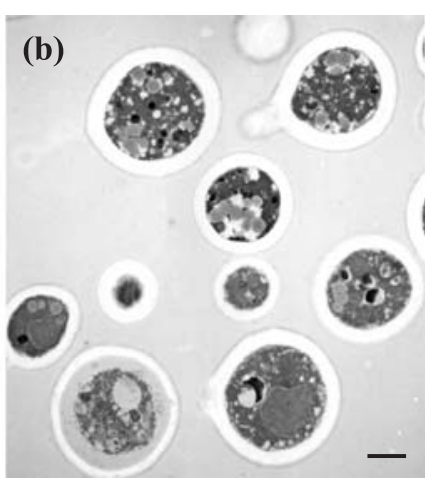

Figure 4. Melanotic-500b (a) and albino-500w (b) C. neoformans cells showing difference in the sizes of the cell walls. Similar results were obtained with the other two pairs of isolates. Scale bars - $1 \mu \mathrm{m}$ (Magnification X 5000).
Table 1. The difference in the cell wall thickness of melanin lacking and melanin producing $C$. neoformans cells.

\begin{tabular}{cc}
\hline Samples & Mean \pm SD $(\mathrm{nm})$ \\
\hline $500 \mathrm{w}$ & $547 \pm 76$ \\
$500 \mathrm{~b}$ & $1087 \pm 103$ \\
$716 \mathrm{w}$ & $566 \pm 72$ \\
$716 \mathrm{~b}$ & $1117 \pm 176$ \\
$764 \mathrm{w}$ & $550 \pm 70$ \\
$764 \mathrm{~b}$ & $1115 \pm 172$ \\
\hline
\end{tabular}

were ranging from 1.0 - $1.1 \mu \mathrm{m}$ (data not shown). The cell wall thickness of the melanotic cells were found to be twice that of the albino cells of similar size. The ratio of cell size (without cell wall) to cell wall size of melanotic cells was 3.6 and that of the albino cells was $5.8(p<0.001)$. The internal structure within the cell wall of the melanin lacking and melanin producing cells were similar.

\section{DISCUSSION}

Melanin synthesis and localization in Cryptococcus neoformans is of particular interest because melanin is critical to pathogenicity and represents a potential target for drug discovery $(6,17)$. Melanin-lacking $C$. neoformans strains are less virulent when compared to melanin producing strains $(15,23)$. The position of the melanin layer is an important factor in determining the function of melanin in protecting the organism from various environmental insults and also in assessing its potential impact on the transport of salts and other constituents across the cell wall. This study was undertaken to detect whether the melanindeficient clinical isolates lack cell wall melanin or if melanin is located in different regions within the visibly albino cells.

In pigmented C. neoformans cells, we found multi-lamellar melanin in the cell wall in mature and recently budded cells, which is in concordance with earlier reports $(6,12,14,20)$. In particular, TEM has previously shown $C$. neoformans melanin is composed of 2-5 layers arranged in concentric manner (8). Studies also have shown that melanin isolated from $C$. neoformans has a layered structure and they are reminiscent of the cell wall $(7,25)$, since multi-lamellate structures are a general characteristic of the cell wall (1). Therefore, structures may exist that direct the deposition of the melanin into the layer. Candidates for this include actin patches surrounding the cell cortex (13) and chitin $(3,27)$.

The cell wall sizes in the study varied from 0.4 to $1.1 \mu \mathrm{m}$ in melanotic cells and 0.3 to $0.7 \mu \mathrm{m}$ in the albino cells depending upon the age of the cells. The melanin layer in the melanotic cells varied in the same proportion. This consequently suggests that the thickness of the cell wall of $C$. neoformans and the melanin layer are directly proportional. 
The albino C. neoformans cells grown in L- DOPA lacked an electron dense layer in the cell wall. We previously showed that the melanin-lacking cells were able to produce laccase, although the enzyme contained a defective copper binding site that may have affected its ability to catalyze the formation of melanin. Additionally, we were previously unable to isolate insoluble black substances during melanin extraction of the albino isolates, (16). The lack of the melanin layer in the albino clinical isolates is consistent with the previous report of melanin lacking mutants of C. neoformans (15).

In conclusion, we have shown that pigmented strains of $C$. neoformans are larger in cell wall size with thick melanin layers in comparison to albino strains isolated from the same patient at the same time. The deposition of melanin in the cell wall is associated with increased virulence and protection from antifungal compounds (16).

\section{ACKNOWLEDGEMENTS}

P.M. is supported by the Council of Scientific and Industrial Research of India [grant number F 9/6(267)/2002-EMR-I] and Indian National Science Academy, New Delhi India. J.D.N. is supported by NIH AI056070-01A2 and AI52733, an Albert Einstein College of Medicine Center for AIDS Research grant, and an Infectious Disease Society of America Wyeth Vaccine Young Investigator Research Award. U.B., T.S.R, I.X. and T.K.D are supported by All India Institute of Medical Sciences, New Delhi, India. U.B. and P.M. gratefully acknowledges support from the AIDS International Training and Research Program (NIH D43- TW01403) of the Albert Einstein College of Medicine for a partial financial assistance during the work (Program Director, V. Prasad).

We thank Frank Macaluso, Analytical Imaging Facility of Albert Einstein College of Medicine, New York, USA, for his expertised help and assistance in processing of the isolates for TEM.

\section{RESUMO}

\section{Isolados clínicos de Cryptococcus neoformans, provenientes da Índia, produtores ou não de melanina: Um estudo em microscopia eletrônica}

Cryptococcus neoformans é um importante fungo oportunista patogênico que causa infecção no sistema nervoso central, e que pode levar o paciente à morte. Um dos principais fatores de virulência do C. neoformans é a produção de melanina na parede celular. Utilizando microscopia eletrônica de transmissão, nós estudamos as paredes celulares de três pares de isolados obtidos de pacientes com dupla infecção pelo fungo, onde um isolado melanizado e um albino foram isolados do líquor de cada paciente. A microscopia eletrônica de transmissão revelou que as cepas albinas não apresentavam a camada de melanina enquanto que uma camada de melanina estava associada com a parede celular de cepas melanóticas, constituindo aproximadamente $75 \%$ da área da parede celular. O tamanho da parede celular das células produtoras de melanina foi aproximadamente o dobro do tamanho da parede celular dos isolados albinos $(\mathrm{p}<0,003)$. Neste estudo, a microscopia eletrônica de transmissão revelou que as diferenças na estrutura dos isolados albinos sem melanina e dos isolados produtores de melanina estava associada à parede celular e a camada de melanina.

Palavras-chave: Cryptococcus neoformans, melanina, microscopia eletrônica de transmissão, parede celular

\section{REFERENCES}

1. Aronson, J.M. (1965). The Cell Wall, in The Fungal Cell (Ainsworth, G.C., and Sussman, A.S., Eds.) pp 49-76, Academic Press, New York.

2. Banerjee, U.; Datta, K.; Majumdar, T.; Gupta, K. (2001). Cryptococcosis in India: the awakening of a giant? Med. Mycol., 39: 51-67.

3. Banks, I.R.; Specht, C.A.; Donlin, M.J.; Gerik, K.J.; Levitz, S.M.; Lodge, J.K. (2005). A Chitin Synthase and Its Regulator Protein Are Critical for Chitosan Production and Growth of the Fungal Pathogen Cryptococcus neoformans. Euk. Cell., 4(11), 1902-1912.

4. Casadevall, A.; Perfect, J.R. (1998). Cryptococcus neoformans. Am. Soc. Microbiol., Washington, D.C.

5. Casadevall, A.; Nosanchuk, J.D. (2002). Melanization of Cryptococcus neoformans and Histoplasma capsulatum reduces their susceptibilities to amphotericin B and caspofungin. Antimicrob. Agents Chemother., 46, 3394-3400.

6. Cassone A.; Simonetti N.; Stripolli V. (1974). Wall structure and bud formation of Cryptococcus neoformans. Arch. Microbiol., 95; $205-$ 212 .

7. al-Doory, Y. (1971). The ultrastructure of Cryptococcus neoformans, Sabouraudia, 9, 115-118.

8. Eisenman, H.C.; Nosanchuk, J.D.; Webber, J.B.W.; Emerson, R.J.; Camesano, T.A.; Casadevall, A. (2005). Microstructure of Cell WallAssociated Melanin in the Human Pathogenic Fungus Cryptococcus neoformans, Biochemistry, 2005, 44, 3683-3693.

9. Garcia-Rivera, J.; Casadevall, A. (2001). Melanization of Cryptococcus neoformans reduces its susceptibility to the antimicrobial effects of silver nitrate, Med. Mycol., 39, 353-357.

10. Huffnagle, G.B.; Chen, G.H.; Curtis, J.L.; McDonald, R.A.; Strieter, R.M.; Toews, G.B. (1995). Down-regulation of the afferent phase of $\mathrm{T}$ cell-mediated pulmonary inflammation and immunity by a high melanin-producing strain of Cryptococcus neoformans. J. Immunol., 155, 3507-3516.

11. Ikeda, R.; Sugita, T.; Jacobson, E.S.; Shinoda, T. (2003). Effects of melanin upon susceptibility of Cryptococcus to antifungals, Microbiol. Immunol., 47, 271-277.

12. Kopecká, M.; Yamaguchi, M.; Gabriel, M.; Takeo, K.; Sovoboda, A. (2000). Morphological Transition during the Cell Division Cycle of Cryptococcus neoformans as Revealed by Transmission Electron Microscopy of Ultrathin Sections and Freeze-Substitution. Scripta Medica, 73: 369-380

13. Kopecka, M.S.; Gabriel, M.; Takeo, K.; Ymaguchi, M.; Svoboda, A.; Ohkusu, M.; Hata, K.; Yoshida, S. (2001). Microtubules and actin cytoskeleton in cryptoccuus neoformans compared with ascomycetous budding and fission yeasts. Eur. J. Cell Biol., 80: 303-311. 
14. Kreger van Rij, N.J.; Veenhuis, M. (1971). A comparative study of the cell wall structure of the of basidiomycetous and related yeasts. J. Gen. Microbiol., 68, 87-95.

15. Kwon-Chung, K.J.; Polacheck, I.; Popkin, T.J. (1982). Melaninlacking mutants of Cryptococcus neoformans and their virulence for mice. J. Bacteriol., 150(3): 1414-1421.

16. Mandal, P.; Banerjee, U.; Casadevall, A.; Nosanchuk, J.D. (2005). Dual Infections with Pigmented and Albino Strains of Cryptococcus neoformans in Patients with or without Human Immunodeficiency Virus Infection in India J. Clin. Microbiol, Sept., p.4766-4772.

17. McFadden, D.C.; Casadevall, A. (2001). Capsule and melanin synthesis in Cryptococcus neoformans. Med. Mycol., 39, 19-30.

18. Mednick, A.J.; Nosanchuk, J.D.; Casadevall, A. (2005). Melanization of Cryptococcus neoformans affects lung inflammatory responses during cryptococcal infection. Infect. Immun., 73: 2012-9.

19. Mylonakis, E.; Ausubel, F.M.; Perfect, J.R.; Heitman, J.; Calderwood, S.B. (2002). Killing of Caenorhabditis elegans by Cryptococcus neoformans as a model of yeast pathogenesis, Proc. Natl. Acad. Sci. U.S.A., 99, 15675-15680.

20. Nosanchuk, J.D.; Valadon, P.; Feldmesser, M.; Casadevall, A. (1999). Melanization of Cryptococcus neoformans in murine infection. Mol. Cell Biol., 19: 745-750.

21. Nosanchuk, J.D.; Casadevall, A. (2003). Budding of melanized Cryptococcus neoformans in the presence or absence of L-dopa, Microbiol., 149, 1945-1951.

22. Rosas, A.L.; Casadevall, A. (1997). Melanization affects susceptibility of Cryptococcus neoformans to heat and cold, FEMS Microbiol. Lett., 153, 265-272.
23. Salas, S.D.; Bennett, J.E.; Kwon-Chung, K.J.; Perfect, J.R.; Williamson, P.R. (1996). Effect of the laccase gene CNLAC1, on virulence of Cryptococcus neoformans, J. Exp. Med., 184, 377-386

24. Steenbergen, J.N.; Shuman, H.A.; Casadevall, A. (2001). Cryptococcus neoformans interactions with amoebae suggest an explanation for its virulence and intracellular pathogenic strategy in macrophages, Proc. Natl. Acad. Sci. U.S.A., 98, 15245-15250.

25. Stoetzner, H.; Kemmer, C. (1971). The morphology of Cryptococcus neoformans in human cryptococcosis. A light-phase-contrast and electron-microscopic study, mycopathol. Mycol. Appl., 45, 327335.

26. Van Duin, D.; Casadevall, A.; Nosanchuk, J.D. (2002). Melanization of Cryptococcus neoformans and Histoplasma capsulatum reduces their susceptibility to amphotericin B and caspofungin. Antimicrob Agents Chemother, 46, 3394-3400.

27. Walton, F.J.; Idnurm, A.; Heitman, J. (2005). Novel gene functions required for melanization of the human pathogen Cryptococcus neoformans. Mol. Microbiol., 57: 1381-1396.

28. Wang, Y.; Casadevall, A. (1994). Decreased susceptibility of melanized Cryptococcus neoformans to UV light, Appl. Environ. Microbiol., 60, 3864-3866.

29. Wang, Y.; Casadevall, A. (1994). Susceptibility of melanized and nonmelanized Cryptococcus neoformans to nitrogen- and oxygenderived oxidants, Infect. Immun., 62, 3004-3007.

30. Wang, Y.; Aisen, P.; Casadevall, A. (1995). Cryptococcus neoformans melanin and virulence: Mechanism of action, Infect. Immun., 63, 3131-3136. 